\title{
Perbandingan Validitas Sistem Penilaian APACHE II, SOFA, dan CSOFA Sebagai Prediktor Mortalitas Pasien yang Dirawat di Instalasi Rawat Intensif Rumah Sakit Umum Pusat H. Adam Malik Medan
}

\author{
Andrias, Achsanuddin Hanafie, Dadik Wahyu Wijaya \\ SMF Anestesiologi dan Terapi Intensif Fakultas Kedokteran Universitas Sumatera Utara/ \\ Rumah Sakit Umum Pusat H. Adam Malik Medan
}

\begin{abstract}
Abstrak
Sistem penilaian APACHE II dan SOFA masih digunakan sebagai instrumen objektif untuk memprediksi mortalitas pasien di Instalasi Rawat Intensif (IRI), namun masih kurang praktis. Sistem penilaian CSOFA dengan parameter serta biaya pengeluaran yang lebih sedikit dan praktis diharapkan memiliki akurasi yang lebih baik. Tujuan penelitian ini mendapatkan alternatif yang lebih sederhana, mudah dan murah, namun tetap memiliki akurasi yang baik sebagai prediktor mortalitas pasien selain APACHE II dan SOFA. Penelitian uji diagnostik cross sectional dilakukan pada bulan Februari-April 2016 di IRI Rumah Sakit Umum Pusat H. Adam Malik. Subjek penelitian 71 pasien dewasa yang memenuhi kriteria inklusi dinilai APACHE II, SOFA, dan CSOFA setelah dirawat 24 jam pertama, kemudian dilihat mortalitasnya pada akhir masa rawatan. Analisis statistik menggunakan tabel $2 \times 2$ serta receiving operating curve (ROC), dihitung juga sensitivitas, spesifisitas, nilai prediksi negatif dan positif, serta likelihood ratio dengan SPSS ver.23. CSOFA memiliki kemampuan yang sangat baik dalam memprediksi mortalitas dengan luas area under ROC (AuROC) 87,6\%. APACHE II memiliki kemampuan yang baik dalam memprediksi mortalitas dengan luas AuROC 84,7\%. SOFA memiliki kemampuan yang cukup dalam memprediksi mortalitas dengan luas AuROC 79,1\%. Simpulan, sistem penilaian CSOFA dapat dijadikan sebagai prediktor mortalitas pasien selain APACHE II dan SOFA di IRI RSUP HAM.
\end{abstract}

Kata kunci: APACHE II, CSOFA, mortalitas, SOFA

\section{Comparison of APACHE II, SOFA, and CSOFA Scoring System Validity as Mortality Predictor in ICU Patients in H. Adam Malik General Hospital}

\begin{abstract}
The APACHE II and SOFA scoring systems are still used as the objective instruments for predicting mortality in patients admitted to the Intensive Care Unit (ICU); however, the two are still considered less practical. CSOFA, with more practical parameters as well as a lower cost, is expected to provide better accuracy. The purpose of this study was to get a simpler, easier, and cheaper alternative, but with good accuracy, to APACHE II and SOFA as a predictor of mortality in patients admitted to the ICU of H. Adam Malik (HAM) Hospital . A cross-sectional diagnostic test study was conducted in February-April 2016 at the ICU of H. Adam Malik General Hospital. A sample of 71 adult patients that met the inclusion criteria was assessed by APACHE II, SOFA, and CSOFA at the first 24 hours after treatment. The mortality was then observed at the end of treatment. Statistical analysis using $2 \times 2$ tables and receiving operating curve (ROC) were used to calculate the sensitivity, specificity, positive, and negative predictive values, as well as the likelihood ratio using SPSS ver.23. CSOFA in this study presented a very good ability in predicting mortality with an Area under ROC (AuROC) of 87.6\% while APACHE II had a good ability in predicting mortality with an AuROC of $84.7 \%$. SOFA had sufficient ability in predicting mortality with an AuROC of 79.1\%. In conclusion, CSOFA scoring system can be used as a patient mortality predictor as an alternative to APACHE II and SOFA in the ICU..
\end{abstract}

Key words: APACHE II, CSOFA, mortality, SOFA

Korespondensi: Andrias, dr., SpAn, SMF Anestesiologi dan Terapi Intensif Fakultas Kedokteran Universitas Sumatera Utara/Rumah Sakit Umum Pusat H. Adam Malik Medan, Jl. Bunga Lau No. 17 Medan 20136, Tlpn. 061-8362080, Mobile 08113718168,Email dr. andrias@gmail.com 


\section{Pendahuluan}

Praktik kedokteran berkembang sangat pesat sehingga banyak pasien penyakit kritis yang sebelumnya tidak terselamatkan, saat ini dapat bertahan hidup dengan perawatan di Instalasi Rawat Intensif (IRI).Sejalan dengan penerapan Sistem Jaminan Kesehatan Nasional melalui Badan Pelayanan Jaminan Sosial, praktisi medis saat ini diharapkan dapat membuat perhitungan dan perkiraan untuk prognosis dari tindakan yang akan dilakukan sehingga perkiraan biaya dapat dibuat dan efisiensi pembiayaan dapat berjalan. ${ }^{1}$

Saat ini penilaian indikasi masuk IRI di Rumah Sakit Umum Pusat H. Adam Malik Medan menggunakan APACHE II dengan kriteria prioritas sesuai Keputusan Menteri Kesehatan Republik Indonesia Nomor 1778/ Menkes/SK/XII/2010, membagi menjadi tiga prioritas ditambah pengecualian sesuai kebijakan kepala IRI. Namun, hal ini belum mampu menjawab prognosis perawatan dijalani oleh pasien sehingga ketersediaan informasi untuk keluarga, penanggung jawab keuangan, rumah sakit, dan praktisi medis sendiri sangat terbatas. Di sisi lain, penggunaan parameter tunggal untuk menilai mortalitas seperti osmolalitas plasma meskipun memiliki nilai prediktor yang cukup baik dengan AuROC 0.75 masih lebih rendah dibanding dengan APACHE II, yaitu $0,83 .^{2}$ Parameter tunggal lain seperti $C$-reactive protein, procalcitonin, lama perawatan, dan usia juga tidak memberikan nilai prediktor yang baik. ${ }^{3-6}$

Sistem penilaian yang lazim dipergunakan IRI di beberapa negara termasuk Indonesia serta digunakan sebagai standar baku adalah penilaian APACHE II.-9 Sistem APACHE II juga memiliki kelemahan karena tidak semua parameter yang diharapkan tersedia di semua fasilitas kesehatan. Sistem penilaian yang lebih sederhana adalah penilaian sequential organ failure assessment (SOFA) yang semula diaplikasikan untuk triage pada pasien sakit kritis di Amerika Serikat. ${ }^{10}$ Penilaian SOFA mengambil empat parameter laboratorium $\left(\mathrm{PaO}_{2}\right.$, kreatinin, bilirubin, dan platelet) serta dua parameter klinis (Glasgow coma scale $=\mathrm{GCS}$ dan kebutuhan vasopresor). Namun, SOFA juga masih kurang praktis karena di sebagian rumah sakit beberapa parameter masih sulit didapatkan $\left(\mathrm{PaO}_{2}\right.$, bilirubin, dan GCS) sehingga dikembangkan modifikasi skor SOFA, yaitu customized sequential organ failure assessment (CSOFA) dan mexican sequential organ failure assessment (MEXSOFA). ${ }^{10,11}$

Berdasar atas hasil penelitian tersebut di atas, nilai validitas tiap-tiap sistem penilaian didapatkan dengan melihat AuROC, yaitu APACHE II 0,892, SOFA 0,919, dan CSOFA $0,9172,{ }^{1}$ sedangkan pada penelitian lainnya didapat AuROC APACHE II 0,69, SOFA 0,73, dan MSOFA $0,75 .^{8}$ Pada hasil penelitian yang membandingkan APACHE II dengan SOFA saja didapat luas AuROC APACHE II 0,912 dan AuROC SOFA 0,951,12 sedangkan pada penelitian yang membandingkan SOFA dengan MEXSOFA didapat luas AuROC SOFA 0,69 dan AuROC MEXSOFA 0,73. ${ }^{11}$ Berdasar atas hasil penelitian di atas, penelitian ini diharapkan dapat membuat modifikasi skor SOFA yang disesuaikan dengan keadaan IRI RSUP HAM yang disebut dengan customized sequential organ failure assessment (CSOFA). Diharapkan CSOFA dapat memberikan akurasi yang lebih baik dibanding dengan APACHE II dan SOFA dengan pengukuran parameter yang lebih praktis dan hanya membutuhkan pemeriksaan yang rutin diperiksa di RSUP HAM. Berangkat dari pemikiran tersebut maka dilakukan penelitian ini yang bertujuan untuk membandingkan validitas sistem penilaian CSOFA, APACHE II, dan SOFA sebagai prediktor mortalitas pada pasien yang dirawat di IRI RSUP HAM.

\section{Subjek dan Metode}

Penelitian ini merupakan uji diagnostik dengan desain cross sectional untuk membandingkan validitas antara APACHE II, SOFA, dan CSOFA dalam memprediksi mortalitas pasien yang dirawat di IRI RSUP HAM. Populasi penelitian ini adalah pasien dewasa yang dirawat di IRI RSUP HAM mulai Februari sampai April 2016.

Seluruh populasi yang memenuhi kriteria inklusi dan tidak termasuk kriteria eksklusi 
dijadikan subjek penelitian. Kriteria inklusi penelitian ini adalah pasien usia di atas 18 tahun. Kriteria eksklusi penelitian ini adalah pasien pulang paksa dan dirawat kurang dari 24 jam di IRI RSUP HAM. Untuk menentukan besar sampel dilakukan perhitungan sesuai dengan penelitian uji diagnostik serta AuC dan didapatkan jumlah sampel 71 orang.

Setelah mendapat persetujuan Komite Etik RSUP HAM/FK-USU maka subjek penelitian diberikan terapi di IRI sesuai dengan panduan praktikklinis.Setelah 24jampertama dilakukan penilaian APACHE II, SOFA, dan CSOFA oleh relawan pemeriksa (peserta PPDS Anestesi Tahap III) yang berbeda berdasar atas tabel penilaian masing-masing. Relawan pemeriksa yang menilai tidak saling mengetahui hasil

\section{Tabel 1 Karakteristik Demografi Subjek} Penelitian

\begin{tabular}{lc}
\hline \multicolumn{1}{c}{ Karakteristik Demografi } & $\mathbf{n}=\mathbf{7 1}$ \\
\hline Jenis kelamin, n (\%) & $33(46)$ \\
Laki-laki & $38(54)$ \\
Perempuan & $48.10(15,05)$ \\
Usia, rata-rata (SB), tahun & \\
Pekerjaan, n (\%) & $29(41)$ \\
Ibu rumah tangga & $16(23)$ \\
Wiraswasta & $7(10)$ \\
Mahasiswa/i & $6(8)$ \\
PNS & $6(8)$ \\
Pegawai swasta & $4(6)$ \\
Buruh & $2(3)$ \\
Petani & $1(1)$ \\
Perawat & \\
Kasus, n (\%) & $49(69)$ \\
Bedah & $22(31)$ \\
Non-bedah & \\
Insufisiensi organ kronik, n (\%) & \\
Ya & $48(68)$ \\
Tidak & $23(32)$ \\
Outcome, n (\%) & \\
Hidup & $33(46)$ \\
Meninggal & $38(54)$ \\
\hline
\end{tabular}

dari sistem penilaian yang lain. Pasien dinilai mortalitas dan kesintasannya saat selesai perawatan di Instalasi Rawat Intensif. Hasil penilaian di-input ke dalam perangkat lunak SPSS ver. 23.

\section{Hasil}

Penelitian ini diikuti oleh 71 subjek penelitian yang telah memenuhi kriteria inklusi. Subjek berjenis kelamin laki-laki 33 orang (46\%) dan subjek berjenis kelamin perempuan 38 orang (54\%) dengan usia rata-rata 48,10 tahun. Sebagian besar subjek (41\%) bekerja sebagai ibu rumah tangga dan jenis kasus yang paling banyak ditemukan ialah kasus bedah 49 orang (69\%). Subjek penelitian yang mengalami insufisiensi organ kronik 48 orang (68\%) dan outcome yang mengalami kematian 38 orang (54\%) serta yang mengalami kesintasan (survival) 33 orang (46\%). Deskripsi lengkap karakteristik demografi subjek penelitian dapat dilihat pada Tabel 1 .

Hasil yang didapatkan dari pengukuran hemodinamik, pemeriksaan laboratorium kimia darah, dan penilaian skor SOFA, CSOFA, serta APACHE II di lapangan dianalisis secara univariat untuk dinilai rata-rata, simpangan baku, nilai minimal dan juga maksimal, serta normalitas distribusi datanya (Tabel 2). Hasil

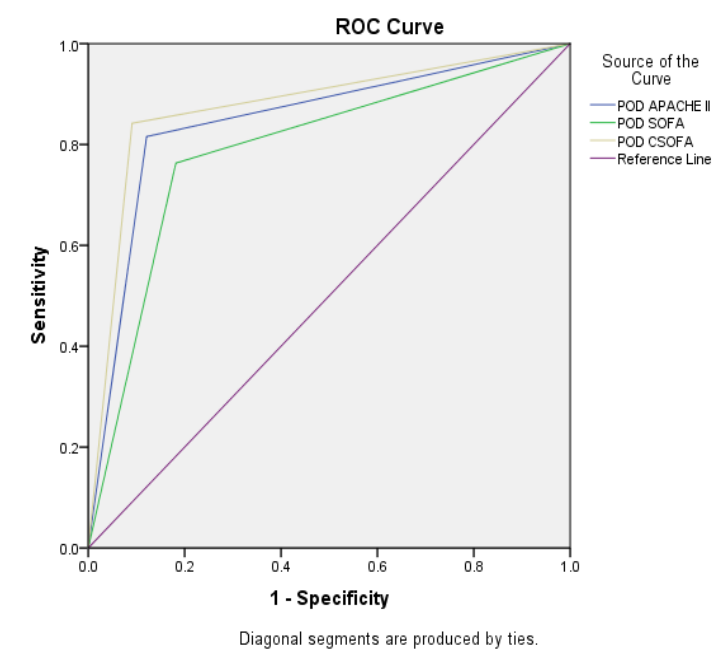

Gambar Perbandingan Luas AUC Sistem Penilaian APACHE II, SOFA, dan CSOFA untuk Memprediksi Mortalitas 
Tabel 2 Karakteristik Klinis dan Laboratorium

\begin{tabular}{lcccc}
\hline \multicolumn{1}{c}{ Karakteristik Klinis dan Laboratorium } & Rata-rata & SB & Min.-Maks. & p $^{*}$ \\
\hline GCS, rata-rata (SB) & 11,42 & 3,905 & $3-15$ & $<0,001$ \\
Suhu, rata-rata (SB), ${ }^{\circ} \mathrm{C}$ & 36,89 & 1,33 & $28,4-38,7$ & $<0,001$ \\
TAR, rata-rata (SB), mmHg & 89,80 & 18,09 & $50-130$ & 0,200 \\
Nadi, rata-rata (SB), x/menit & 101,49 & 22,58 & $45-153$ & 0,200 \\
Napas, rata-rata (SB), x/menit & 18,15 & 5,03 & $12-35$ & $<0,001$ \\
PO $_{2}$, rata-rata (SB), mmHg & 163,49 & 41,6 & $80-236$ & 0,001 \\
pH, rata-rata (SB) $_{\text {Natrium, rata-rata (SB),mEq/L }}^{7,33}$ & 0,12 & $6,98-7,57$ & 0,002 \\
Kalium, rata-rata (SB),mEq/L & 137,13 & 7,01 & $107-155$ & 0,067 \\
Kreatinin, rata-rata (SB), mg/dL & 3,96 & 0,78 & $2,0-6,5$ & 0,007 \\
Hematokrit, rata-rata (SB), \% & 1,87 & 3,06 & $0,4-20,7$ & $<0,001$ \\
Leukosit, rata-rata (SB), mm ${ }^{-3}$ & 35,1 & 8,27 & $15-55$ & 0,200 \\
P/F Ratio, rata-rata (SB) & 15,82 & 6,52 & $3,2-32,9$ & 0,018 \\
S/F Ratio, rata-rata (SB) & 375,68 & 133,6 & $132-693$ & 0,099 \\
Bilirubin, rata-rata (SB) & 221,69 & 43 & $110-341$ & $<0,001$ \\
APACHE II, rata-rata (SB) & 1,22 & 1,11 & $0,1-8,0$ & $<0,001$ \\
SOFA, rata-rata (SB) & 15,07 & 8,46 & $1-36$ & $<0,001$ \\
CSOFA, rata-rata (SB) & 7,76 & 5,11 & $0-18$ & $<0,001$ \\
LOS, rata-rata (SB), hari & 7,65 & 5,16 & $0-21$ & $<0,001$ \\
\hline
\end{tabular}

Keterangan: *Kolmogorov Smirnov

penilaian CSOFA rata-rata7,65 dengan nilai terendah 0 dan tertinggi 21 . Hasil pengukuran APACHE II nilai terendah adalah 1 dan tertinggi 36 dengan rata-rata 19,64 . Hasil penilaian SOFA memiliki rata-rata 7,76 dengan nilai terendah 0 dan tertinggi 18.

Analisis data dilakukan dengan tabel $2 \times 2$ kemudian dihitung sensitivitas, spesifisitas, NDP, NDN, RKP, dan RKN dari tiap-tiap sistem penilaian (Tabel 3). Pada sistem penilaian APACHE II dengan menggunakan nilai cut-off 20 maka diperoleh sensitivitas dan spesifisitas dalam memprediksi mortalitas adalah 81\% dan $87 \%$ dengan nilai duga positif $88 \%$ dan

Tabel 3 Sensitivitas, Spesifisitas, Nilai Duga Positif (NDP), Nilai Duga Negatif (NDN), Rasio Kemungkinan Positif (RKP) dan Rasio Kemungkinan Negatif (RKN) dari Sistem Penilaian APACHE II, SOFA, dan CSOFA terhadap Mortalitas

\begin{tabular}{|c|c|c|c|c|c|c|c|c|c|}
\hline \multirow{2}{*}{\multicolumn{2}{|c|}{$\begin{array}{c}\text { Sistem Penilaian } \\
\text { Meninggal }\end{array}$}} & \multirow{2}{*}{\multicolumn{2}{|c|}{ Outcome }} & \multirow{2}{*}{ Sensitivitas } & \multirow{2}{*}{ Spesifisitas } & \multirow{2}{*}{ NDP } & \multirow{2}{*}{ NDN } & \multirow{2}{*}{ RKP } & \multirow{2}{*}{ RKN } \\
\hline & & & & & & & & & \\
\hline \multirow{2}{*}{ APACHE II } & Meninggal & 31 & 4 & \multirow{2}{*}{$81 \%$} & \multirow{2}{*}{$87 \%$} & \multirow{2}{*}{$88 \%$} & \multirow{2}{*}{$80 \%$} & \multirow{2}{*}{6,75} & \multirow{2}{*}{0,20} \\
\hline & Hidup & 7 & 29 & & & & & & \\
\hline \multirow{2}{*}{ SOFA } & Meninggal & 29 & 6 & \multirow{2}{*}{$76 \%$} & \multirow{2}{*}{$82 \%$} & \multirow{2}{*}{$83 \%$} & \multirow{2}{*}{$75 \%$} & \multirow{2}{*}{4,22} & \multirow{2}{*}{0,29} \\
\hline & Hidup & 9 & 27 & & & & & & \\
\hline \multirow{2}{*}{ CSOFA } & Meninggal & 32 & 3 & \multirow{2}{*}{$84 \%$} & \multirow{2}{*}{$90 \%$} & \multirow{2}{*}{$91 \%$} & \multirow{2}{*}{$83 \%$} & \multirow{2}{*}{9,33} & \multirow{2}{*}{0,16} \\
\hline & Hidup & 6 & 30 & & & & & & \\
\hline
\end{tabular}


nilai duga negatif $80 \%$. Pada sistem penilaian SOFA dengan menggunakan nilai cut-off 11 maka diperoleh sensitivitas serta spesifisitas dalam memprediksi mortalitas 76\% dan $82 \%$ dengan nilai duga positif $83 \%$ dan nilai duga negatif $75 \%$. Pada sistem penilaian CSOFA dengan mempergunakan nilai cut-off 10 maka diperoleh sensitivitas dan spesifisitas dalam memprediksi mortalitas $84 \%$ dan $90 \%$ dengan nilai duga positif $91 \%$ dan nilai duga negatif $83 \%$.

Luas AuC paling besar berasal dari ROC sistem penilaian CSOFA yaitu $87,6 \%$, diikuti oleh APACHE II 84,7\% dan yang memiliki AuC paling kecil adalah ROC SOFA 79,1\% (Gambar).

\section{Pembahasan}

Penentuan tingkat mortalitas merupakan hal penting dalam rangkaian rencana tindak lanjut perawatan pasien di IRI. Banyak penelitian telah dilakukan untuk menemukan prediktor mortalitas yang baik terhadap pasien yang dirawat di IRI. Sistem penilaian APACHE II merupakan sistem penilaian yang telah diakui kesahihannya dalam memprediksi mortalitas pasien.

Skor APACHE II pertama kali dikembangkan oleh Knaus dkk. pada tahun 1985 dengan menggunakan tiga komponen penilaian; acute physiological score (APS), komponen terbesar yang diturunkan dari 12 pengukuran klinis yang didapatkan dalam 24 jam perawatan di IRI. Hasil pengukuran yang paling abnormal dipergunakan untuk menghasilkan komponen APS untuk skor APACHE II. Jika ada variabel yang tidak diukur maka dianggap memiliki nilai $0 .{ }^{13}$ Penilaian APACHE II hingga saat ini masih menjadi pilihan sebagai prediktor mortalitas pasien yang dirawat di IRI. Namun, ada beberapa kendala yang ditemukan pada penilaian APACHE II seperti biaya yang lebih besar akibat banyak variabel laboratorium yang diperiksa dan waktu untuk mendapatkan hasil yang cukup lama. Ada beberapa sistem penilaian alternatif yang telah diteliti untuk menentukan tingkat mortalitas pasien, seperti MEXSOFA, SOFA, MSOFA, dan CSOFA., ${ }^{8,10,11}$

Sistem penilaian APACHE II dan SOFA saat ini digunakan pada berbagai IRI di benua Eropa dan Amerika. Namun, kedua sistem penilaian ini memiliki kelemahan yang sejalan dengan peningkatan kualitas manajemen kesehatan, dengan demikian kedua sistem penilaian di atas menjadi overestimate dan kurang efisien serta tidak cost effective dalam memprediksi mortalitas. ${ }^{14}$ Penilaian skor CSOFA merupakan bentuk penyederhanaan dari sistem penilaian skor SOFA yang dilakukan untuk mengurangi pemeriksaan laboratorium sehingga penilaian ini dapat dilakukan dengan lebih cepat serta prediksi mortalitas menjadi lebih efisien dan cost effective. Modifikasi yang dilakukan pada CSOFA adalah: 1.) mensubstitusi rasio $\mathrm{PaO}_{2} /$ $\mathrm{FiO}_{2}$ menjadi rasio $\mathrm{SpO}_{2} / \mathrm{FiO}_{2} ; 2$.) parameter bilirubin diganti dengan ikterik; 3.) parameter lain tetap digunakan.

Hasil penelitian dengan subjek penelitian sebanyak 71 orang ini menyatakan bahwa sistem penilaian pada APACHE II mempunyai kemampuan yang baik untuk memprediksi mortalitas. Berdasarkan pada ROC, diperoleh luas AuROC adalah 84,7\%. Sensitivitas sistem penilaian skor APACHE II dalam memprediksi mortalitas adalah $81 \%$ dengan spesifisitas $87 \%$. Hasil ini serupa dengan penelitian yang dilakukan oleh Sunaryo dkk.12 bahwa luas AuROC untuk sistem penilaian APACHE II $91,2 \%$.

Sistem penilaian skor SOFA pada penelitian ini memiliki kemampuan yang cukup dalam memprediksi mortalitas, dengan menggunakan ROC diperoleh luas AuROC 79,1\%. Sensitivitas sistem penilaian SOFA dalam memprediksi mortalitas sebesar $76 \%$ dengan spesifisitas yang mencapai $82 \%$. Pada penelitian yang dilakukan oleh Dino dkk. didapat luas AuROC sistem penilaian SOFA adalah $73 \%$. Perbedaan tersebut dapat dipengaruhi oleh perbedaan karakteristik pasien serta tidak homogennya sistem pelayanan kesehatan sehingga kondisi tersebut dapat memengaruhi angka prediksi mortalitas pasien yang menggunakan sistem penilaian SOFA. Sistem penilaian CSOFA pada penelitian ini mempunyai kemampuan yang baik dalam memprediksi mortalitas dengan luas AuROC sebesar 87,6\%. Sensitivitas sistem penilaianCSOFAdalammemprediksimortalitas 
sebesar 84\% dengan spesifisitas mencapai $90 \%$. Hal ini sesuai dengan penelitian yang dilakukan oleh Taofik dkk. ${ }^{1}$ bahwa luas AuROC sistem penilaian CSOFA untuk memprediksi mortalitas adalah sebesar $91,72 \%$. Penelitian ini juga melihat perbandingan antara nilai $\mathrm{AuC}$ sistem penilaian APACHE II, SOFA, dan CSOFA dalam memprediksi mortalitas pasien yang dirawat di IRI RSUP HAM. Dari hasil penelitian ini diperoleh bahwa AuROC CSOFA memiliki luas terbesar, yaitu $87,6 \%$, yang berarti sistem penilaian CSOFA memiliki kemampuan yang paling baik sebagai prediktor mortalitas bila dibanding dengan APACHE II dan SOFA.

Berdasar atas hasil dan pembahasan di atas didapatkan bahwa sistem penilaian CSOFA memiliki validitas yang lebih tinggi dibanding dengan dua sistem penilaian APACHE II dan SOFA. Dengan demikian, penilaian skor CSOFA dapat dijadikan sebagai prediktor mortalitas pasien yang dirawat di IRI RSUP HAM Medan.

\section{Simpulan}

Simpulan penelitian ini adalah bahwa sistem penilaian APACHE II, SOFA, dan CSOFA dapat digunakan sebagai prediktor mortalitas dan CSOFA dapat menggantikan APACHE II sebagai prediktor mortalitas pasien di IRI RSUP HAM dengan mengacu pada CSOFA memiliki luas AuROC terbesar dibanding dengan APACHE II dan SOFA.

\section{Daftar Pustaka}

1. Taofik S, Senapathi TGA, Wiryana M. Perbandingan validitas sistem skoring APACHE II, SOFA, dan customized sequential organ failure assessment (CSOFA) untuk memperkirakan mortalitas pasien non-bedah yang dirawat di ruang perawatan intensif. J Anestesiologi Indonesia. 2015;7(2):102-13.

2. Wardani IP. Osmolaritas plasma sebagai alternatif APACHE II untuk prediktor mortalitas pada pasien kritis yang dirawat di ICU RSUP Sanglah. Bali: Bagian Ilmu Anestesi dan Terapi Intensif FK Udayana; 2014.
3. Dahaba AA, Hagara B, Fall A, Rehak PH. Procalcitionin for early prediction of survival outcome in postoperative critically ill patients with severe sepsis. $\mathrm{Br}$ J Anaesth. 2006;97(4):503-8.

4. Al-Subaie N, Reynold T, Myers A. C-reactive protein as a predictor of outcome after discharge from intensive care: a prospective observational study. $\mathrm{Br} \mathrm{J}$ Anaesth. 2010;105(3):318-25.

5. Williams TA1, Ho KM, Dobb GJ, Finn JC, Knuiman M, Webb SA, dkk. Effect of length of stay in intensive care unit on hospital and long-term mortality of critically ill adult patients. Br J Anaesth. 2010;104(4):45964.

6. Hood E, Bhangu A, Pandit A, Michael A. Is age a predictor of mortality in an UK Medical High Dependency Unit?. Br J Anaesth. 2011;107(2):186-92.

7. Bouch DC, Thompson JP. Severity scoring systems in the critically ill. Continuing education in anesthesia. Crit Care Pain. 2008;8(5):181-5.

8. Halim DA, Murni TW, Ike SR. Comparison of APACHE II, SOFA, and modified SOFA scores in predicting mortality of surgical patients in Intensive Care Unit at Dr. Hasan Sadikin General Hospital. Crit Care Shock. 2009;12(4):157-69.

9. Aftab H, Patil S, Parcells AL, Chamberlain RS. The simplified acute physiology score iii is superior to the simplified acute physiology score II and acute physiology and chronic health evaluation II in predicting surgical and ICU mortality in the oldest old. Curr Gerontol Geriatrics Res. 2014;2014(1):1-9.

10. Grissom CK, Brown SM, Kuttler KG, Boltax JP. A Modified Sequential Organ Failure Assessment (MSOFA) for Critical Care Triage. Disaster Med Public Health Prep. 2010;4(1):277-84.

11. Namendy-silva SA, Medina-silva MA, Barahona VGM, Torres JAB. Application of modified sequential organ failure assessment score to critically ill patients. Braz J Med Biol Res. 2013;46(2):186-93.

12. Sunaryo A, Ike SR, BisriT. Perbandingan 
validasi APACHE II dan SOFA score untuk memperkirakan mortalitas pasien yang dirawat di ruang perawatan intensif. Majalah Kedokteran Terapi Intensif. 2012;2(1):11-20.

13. Sakr Y, Krauss C, Amaral ACKB, Reinhart K. Comparison of the performance of SAPS II, SAPS III, APACHE II, and their customized models in a surgical intensive care unit. $\mathrm{Br}$ J Anesth. 2008;101(6):798-803.

14. Timmers TK, Verhofstad MHJ, Moons KGM. Validation of six mortality prediction systems for ICU surgical populations. Netherland J Crit Care. 2011;15(3):11830 . 